\title{
KARAKTERISTIK ERAPAN NITRAT PADA ANDISOL
}

\section{Characteristics of Nitrate Sorption of Andisols}

\author{
Arief Hartono1), Syaiful Anwar1) dan Masruroh2) \\ 1) Departemen Ilmu Tanah dan Sumberdaya Lahan, Fakultas Pertanian, IPB University, J1. Meranti Kampus IPB \\ Darmaga Bogor 16680 \\ 2) Program Studi Manajemen Sumberdaya Lahan, IPB University, Jl. Meranti Kampus IPB Darmaga Bogor 16680
}

\begin{abstract}
Excessive use of urea and livestock manure by farmers causes the accumulation of nitrate ions on agricultural soils. Knowledge of the ability of soil to absorb nitrate is very important in terms of nitrate movement in the soil profile. The objectives of this study was to reveal the ability of the soils to bind nitrate through sorption and to reveal the soil properties affect the nitrate sorption. Nitrate sorption data were obtained by saturating the soil with nitrate solutions at various concentrations, after previously saturating the soil with chloride ions. Nitrates in the supernatant solution were determined using a UV Spectrophotometer with a wavelength of $210 \mathrm{~nm}$ and $275 \mathrm{~nm}$. Then, the data were analyzed using two equations, namely, Langmuir equation and Freundlich equation. The results showed that the nitrate sorptions were best simulated by the Freundlich equation. The value of the constant $K$ Freundlich equation as index of nitrate sorption maximum had a positive correlation with the organic carbon $(C)$, aluminium extracted by ammonium oxalate $\left(A l_{o}\right)$, aluminium extracted by Dithonite-citrate-bicarbonate $\left(A l_{d}\right)$ and $A l_{o}+1 / 2 F_{o}$ (Andic property). The results suggested that organic $C, A l_{o}, A l_{d}$, and Andic property could be considered to control nitrate sorption.
\end{abstract}

Keywords: Freundlich, Langmuir, soil properties, urea

\section{ABSTRAK}

Penggunaan pupuk urea dan pupuk kandang yang berlebihan oleh petani menyebabkan terjadinya akumulasi ion nitrat pada tanah pertanian. Pengetahuan tentang kemampuan tanah dalam mengerap nitrat menjadi sangat penting dalam kaitan pergerakan nitrat di dalam profil tanah. Tujuan penelitian ini adalah karakterisasi tanah-tanah pertanian yang mempunyai order Andisol di Pulau Jawa dalam mengerap nitrat dan mengidentifikasi sifat-sifat tanah yang mempengaruhi erapan nitrat. Data erapan nitrat diperoleh dengan menjenuhkan tanah dengan larutan nitrat pada berbagai konsentrasi, setelah sebelumnya tanah dijenuhi dengan ion klorida. Nitrat dalam larutan supernatan ditetapkan menggunakan UV Spectrophotometer dengan panjang gelombang $210 \mathrm{~nm}$ dan $275 \mathrm{~nm}$. Kemudian, data dianalisis menggunakan dua persamaan yaitu, persamaan Langmuir dan persamaan Freundlich. Hasil menunjukkan bahwa erapan nitrat dapat disimulasikan paling baik oleh persamaan Freundlich. Nilai konstanta $K$ persamaan Freundlich yang merupakan indeks erapan maksimum berkorelasi positif dengan karbon (C) organik, aluminium yang diekstrak dengan amonium oksalat $\left(\mathrm{Al}_{\mathrm{o}}\right)$, aluminium yang diekstrak dengan dithionite-citratebicarbonate $\left(\mathrm{Al}_{\mathrm{d}}\right)$ dan $\mathrm{Al}_{\mathrm{o}}+1 / 2 \mathrm{Fe}_{\mathrm{o}}$ (sifat Andik). Penelitian ini merekomendasikan bahwa $\mathrm{C}$ organik, $\mathrm{Al}_{\mathrm{o}}, \mathrm{Al}_{\mathrm{d}}$ dan sifat $\mathrm{Andik}$ mengontrol erapan nitrat.

Kata kunci: Freundlich, Langmuir, sifat tanah, urea

\section{PENDAHULUAN}

\section{Latar Belakang}

Penggunaan pupuk urea dan pupuk kandang pada lahan-lahan pertanian dengan tanah dengan order Andisol sebagai sumber pupuk nitrogen oleh petani sangat besar sehingga ada kekhawatiran bahwa telah terjadi pencemaran ion nitrat pada air tanah. Pengetahuan tentang kemampuan tanah dalam mengerap nitrat menjadi sangat penting dalam kaitan pergerakan nitrat di dalam profil tanah sampai pada air tanah.

Erapan nitrat pada koloid tanah umumnya karena ikatan elektrostatik. Ikatan elektrostatik ini terjadi karena adanya muatan positif pada partikel tanah yang berasal dari proses protonisasi gugus hidroksil pada mineral aluminium (Al) dan besi (Fe) hidrus oksida atau pada gugus hidroksil mineral klei alofan dan imogilit (Tani et al., 2004; Maeda et al., 2008). Muatan positif yang ada di partikel tanah ini menarik ion nitrat menjadi nitrat yang tererap. Muatan positif pada tanah pertanian dapat mengurangi kontaminasi air tanah oleh nitrat.

Tipe-tipe mineral klei menentukan dalam kemampuan tanah dalam mengerap anion-anion (Wada, 1959; Van Ranst et al. 2004) karena terkait dengan proses protonasi gugus hidroksil. Dominansi tipe mineral klei berbeda-beda setiap jenis tanah. Andisol tanah yang terbentuk dari abu vulkan didominasi oleh mineral klei silikat alofan dan mineral klei Al dan Fe hidrus oksida amorf (Tan dan Van Schuylenborgh, 1961; Tan, 1965). Penelitian sebelumnya pada Andisols di Indonesia yang terkait dengan erapan anion adalah penelitian tentang fosfat (Hartono, 2007; Hartono et al., 2007; Hartono dan Bilhaq, 2014). Penelitian tentang erapan nitrat pada Andisol belum banyak terdokumentasi.

Karakterisasi erapan nitrat sangat spesifik lokasi, oleh karena itu perlu dicari lebih jauh sifat-sifat kimia tanah apa saja yang berpengaruh terhadap erapan nitrat pada 
Andisol. Tujuan penelitian ini adalah karakterisasi pola erapan nitrat pada Andisols dengan sifat fisiko-kimia yang berbeda.

\section{BAHAN DAN METODE}

\section{Waktu Dan Tempat Pengambilan Contoh Tanah dan Pelaksanaan Penelitian}

Penelitian ini dilakukan dari bulan Desember 2013 sampai Maret 2014. Contoh-contoh tanah diambil dari 19 contoh Andisol yang berasal dari Jawa Barat dan Jawa Timur dengan kisaran ketinggian 502 meter (m) di atas permukaan laut (dpl) sampai 1,240 m dpl. Contoh-contoh tanah Andisol dari Jawa Barat diambil di Pengalengan, Lembang, Cimacan, Kawah Putih, Malangbong, Cicalengka, dan Darandang. Contoh-contoh tanah Andisol dari Jawa Timur diambil di Batu Malang dan Ngantang. Beberapa contoh tanah diambil pada kedalaman yang berbeda dalam satu profil tanah. Sebaran pengambilan contoh Andisol disajikan pada Gambar 1. Analisis tanah dilakukan di Laboratorium kimia dan Kesuburan Tanah, Departemen Ilmu Tanah Dan Sumberdaya Lahan Fakultas Pertanian, IPB University. Data tanah Andisol Lembang kedalaman 0-16 cm dan Pangalengan kedalaman 0-21 cm diambil dari data yang dipublikasikan oleh Hartono et al. (2019).

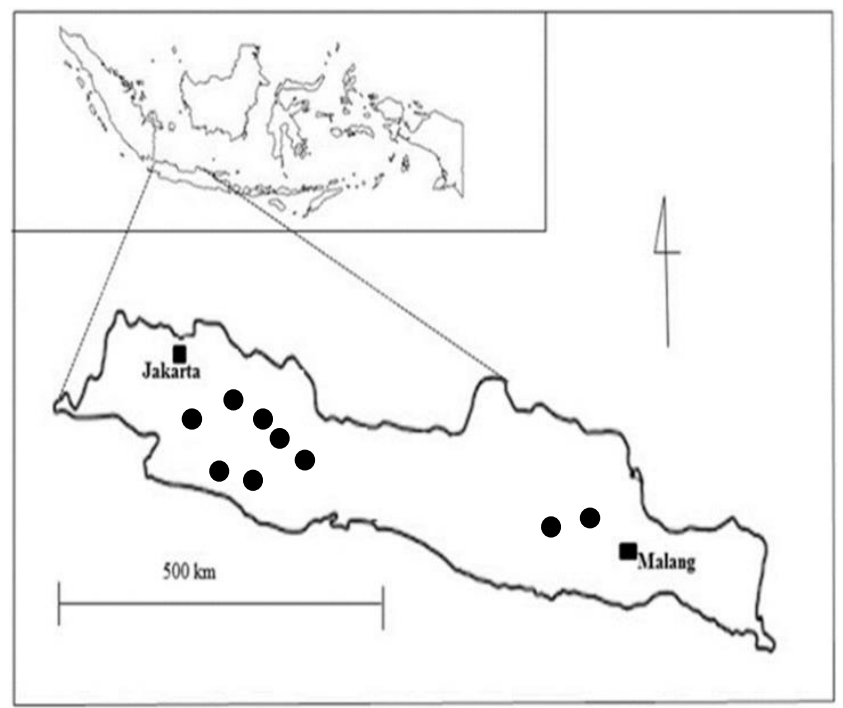

Gambar 1. Sebaran contoh tanah Andisol yang digunakan dalam penelitian

\section{Karakterisasi Sifat Fisiko-Kimia}

Bahan tanah dikering-udarakan, ditumbuk kemudian diayak menggunakan saringan ukuran 2-mm (Eimer and Amend). Penetapan $\mathrm{pH}$ tanah 1:5 (m/v) menggunakan pH meter (Eutech Instruments pH 2700). Tekstur tanah ditetapkan menggunakan metode pipet. Kandungan C-organik ditetapkan menggunakan metode Walkley dan Black. Kapasitas tukar kation (KTK) dilakukan dengan mengekstraksi kation-kation menggunakan 1 mol L-1 $\mathrm{NH}_{4} \mathrm{OAc} \mathrm{pH} 7.0$, selanjutnya penetapan KTK menggunakan metode titrasi. Analisis $\mathrm{P}$ tersedia ditetapkan menggunakan metode Bray 1. Kriteria penilaian hasil analisis berdasarkan kriteria penilaian Balai Penelitian Tanah (2009).

Oksida besi $(\mathrm{Fe})$ dan aluminum $(\mathrm{Al})$ yang kristalin diekstrak menggunakkan pengekstrak dithionite-circatebicarbonate berdasarkan metode Mehra dan Jackson (1960) dan untuk selanjutnya disebut $\mathrm{Fe}_{\mathrm{d}}$ dan $\mathrm{Al}_{\mathrm{d}}$. Oksida-oksida $\mathrm{Fe}$ dan $\mathrm{Al}$ yang amorf diekstrak menggunakan pengekstrak $0.3 \mathrm{~mol} \mathrm{~L}^{-1}$ ammonium oxalate berdasarkan metode McKeague dan Day (1966) untuk selanjutnya disebut $\mathrm{Fe}_{\mathrm{o}}$ dan $\mathrm{Al}_{\mathrm{o}}$.

\section{Karakterisasi Erapan Nitrat}

Data erapan nitrat diperoleh dengan menggunakan prosedur yang dipublikasikan oleh Fox dan Kamprath (1970). Contoh tanah dijenuhi dengan ion $\mathrm{Cl}^{-}$menggunakan larutan $1 \mathrm{~mol} \mathrm{~L}^{-1} \mathrm{KCl}$. Ion $\mathrm{Cl}^{-}$yang berlebih dalam contoh tanah kemudian dicuci menggunakan air destilata. Setelah itu tanah dikeringudarakan sebelum digunakan pada percobaan erapan nitrat. Kemudian 2.00 gram contoh tanah ditimbang dan dimasukkan dalam tabung sentrifus $50 \mathrm{~mL}$. Setelah itu ditambahkan $5 \mathrm{~mL}$ larutan $\mathrm{KNO}_{3}$ dengan konsentrasi $0.001,0.005,0.01,0.04,0.08,0.10$, dan 0.20 mol L ${ }^{-1}$. Tabung sentrifus dikocok dengan mesin pengocok (Eyela Multi Shaker MMS) selama 2 jam kemudian disentrifuse dengan alat sentrifus (International Centrifuge Size 2 Model K No $3225 \mathrm{M}$ ) selama 15 menit dengan kecepatan $2500 \mathrm{rpm}$ (Tani et al., 2004). Supernatan dalam tabung sentrifus setelah itu disaring menggunakan kertas saring $0.45 \mu \mathrm{m}$ dimana penyaringan menggunakan vacuum machine (GAST Manufacturing.ins DOA-P104-BN) untuk mendapatkan larutan yang jernih. Nitrat dalam larutan ditetapkan menggunakan $U$ V spectrophotometer (Shimadzu UV-1201) dengan panjang gelombang $210 \mathrm{~nm}$ dan $275 \mathrm{~nm}$. Panjang gelombang $275 \mathrm{~nm}$ digunakan untuk mengkoreksi adanya bahan organik yang terlarut. Oleh karena itu pembacaan absorban pada panjang gelombang $210 \mathrm{~nm}$ harus dikurangi dengan 2.5 kali pembacaan absorban pada panjang gelombang $275 \mathrm{~nm}$.

\section{Simulasi Data Erapan Nitrat}

Data erapan nitrat disimulasikan dengan persamaan Langmuir dan persamaan Freundlich. Persamaan Langmuir ditulis sebagai berikut (Hartono et al. 2005):

$$
\mathrm{q}=(K b C) /(1+K C)
$$

Bentuk linear persamaan Langmuir adalah:

$$
C / \mathrm{q}=(1 / K b)+(1 / b) C
$$

dimana $\mathrm{q}$ adalah nitrat yang dierap dalam mmol $\mathrm{g}^{-1}, C$ adalah konsentrasi nitrat dalam larutan kesetimbangan dalam mmol $\mathrm{L}^{-1}, K$ (konstanta energi ikatan $\mathrm{P}$ ) dalam $\mathrm{L}$ $\mathrm{mmol}^{-1}$ dan $b$ (erapan maksimum) dalam mmol $\mathrm{g}^{-1}$.

Persamaan Freundlich disajikan seperti di bawah ini:

$$
\mathrm{q}=\mathrm{K} C^{1 / \mathrm{n}}
$$

dimana $\mathrm{q}$ adalah nitrat yang dierap dalam mmol $\mathrm{g}^{-1}, C$ adalah konsentrasi nitrat dalam larutan kesetimbangan dalam mmol $\mathrm{L}^{-1}$. $\mathrm{K}$ dan $\mathrm{n}$ merupakan konstanta empirik. 
Persamaan non-linear Freundlich dalam bentuk linear disajikan seperti di bawah ini:

$$
\log q=\log K+1 / n \log C
$$

dimana $\mathrm{K}$ dan $\mathrm{n}$ adalah konstanta dimana konstanta $\mathrm{K}$ menunjukkan erapan maksimum.

\section{Analisis Statistik}

Uji korelasi digunakan untuk mengetahui sifatsifat kimia tanah yang mempunyai hubungan erat dengan nilai parameter-parameter dari persamaan Langmuir dan Freundlich.

\section{HASIL DAN PEMBAHASAN}

\section{Sifat Fisiko-kimia Contoh-contoh Tanah Percobaan}

Sifat fisiko-kimia tanah yang digunakan disajikan pada Tabel 1. Nilai $\mathrm{pH}$ tanah berkisar dari 4.71 (masam) sampai 7.11 (netral) dengan nilai rata-rata 5.63 (agak masam). KTK tanah berkisar dari 13.8 cmol $_{\mathrm{c}} \mathrm{kg}^{-1}$ (rendah) sampai $39.0 \mathrm{cmol}_{\mathrm{c}} \mathrm{kg}^{-1}$ (tinggi) dengan nilai rata-rata 25.8 $\mathrm{cmol}_{\mathrm{c}} \mathrm{kg}^{-1}$ (tinggi). Kadar $\mathrm{P}$ tersedia pada tanah berkisar dari $49.2 \mathrm{mg} \mathrm{P}_{2} \mathrm{O}_{5} \mathrm{~kg}^{-1}$ (sangat tinggi) sampai dengan 302 $\mathrm{mg}_{2} \mathrm{O}_{5} \mathrm{~kg}^{-1}$ (sangat tinggi) dengan nilai rata-rata $111 \mathrm{mg}$ $\mathrm{P}_{2} \mathrm{O}_{5} \mathrm{~kg}^{-1}$ (sangat tinggi). C-organik berkisar dari $1.15 \%$ (rendah) sampai 8.88\% (sangat tinggi) dengan nilai rata-rata $5.10 \%$ (tinggi). Total $\mathrm{N}$ berkisar dari $0.15 \%$ (sangat rendah) sampai $0.68 \%$ (tinggi) dengan nilai rata-rata $0.35 \%$ (sedang)

$\mathrm{Al}_{\mathrm{o}}$ berkisar dari $6.60 \mathrm{~g} \mathrm{~kg}^{-1}$ sampai dengan $212 \mathrm{~g}$ $\mathrm{kg}^{-1}$ dengan nilai rata-rata $62.4 \mathrm{~g} \mathrm{~kg}^{-1}$. Fe $\mathrm{F}_{\mathrm{o}}$ berkisar dari 5.55 $\mathrm{g} \mathrm{kg}^{-1}$ sampai dengan $92.5 \mathrm{~g} \mathrm{~kg}^{-1}$ dengan nilai rata-rata 21.1 $\mathrm{g} \mathrm{kg}^{-1} . \mathrm{Al}_{\mathrm{o}}+1 / 2 \mathrm{Fe}_{\mathrm{o}}$ berkisar dari $13.9 \mathrm{~g} \mathrm{~kg}^{-1}$ sampai dengan $258 \mathrm{~g} \mathrm{~kg}^{-1}$ dengan nilai rata-rata $73.0 \mathrm{~g} \mathrm{~kg}^{-1}$. $\mathrm{Al}_{\mathrm{d}}$ berkisar dari $2.33 \mathrm{~g} \mathrm{~kg}^{-1}$ sampai dengan $25.6 \mathrm{~g} \mathrm{~kg}^{-1}$ dengan nilai ratarata $8.19 \mathrm{~g} \mathrm{~kg}^{-1}$. Fe $\mathrm{d}_{\mathrm{d}}$ berkisar $13.6 \mathrm{~g} \mathrm{~kg}^{-1}$ sampai dengan 81.6 $\mathrm{g} \mathrm{kg}^{-1}$ dengan nilai rata-rata $40.1 \mathrm{~g} \mathrm{~kg}^{-1}$. Kadar klei berkisar dari $11.0 \%$ sampai dengan $71.6 \%$ dengan nilai rata-rata sebesar $39.0 \%$.

Hasil analisis pendahuluan menunjukkan bahwa tanah-tanah yang digunakan mempunyai sifat fisiko-kimia yang bervariasi ditandai dengan nilai standar deviasi setiap parameter yang relatif tinggi (Tabel 1) sehingga mewakili variasi sifat kimia tanah dalam mengerap nitrat.

\section{Erapan nitrat}

Data erapan nitrat disimulasikan dengan persamaan Langmuir dan Freundlich. Paramater persamaan Langmuir dan nilai $\mathrm{R}^{2}$ disajikan pada Tabel 2. Nilai $K$ dan $b$ hampir semua contoh tanah bernilai negatif dan nilai $\mathrm{R}^{2}$ persamaan Langmuir dalam bentuk linear sangat kecil. Hasil ini menunjukkan bahwa nitrat tidak dapat disimulasikan dengan persamaan Langmuir. Gambar 2 adalah contoh persamaan Langmuir dalam bentuk linear Andisol Kawah Putih 0-15 cm dimana nilai $\mathrm{R}^{2}$ persamaan linearnya 0.080 . Hal ini berbeda dengan yang dilaporkan Tani et al. (2004) bahwa data erapan nitrat dapat disimulasikan dengan persamaan Langmuir.

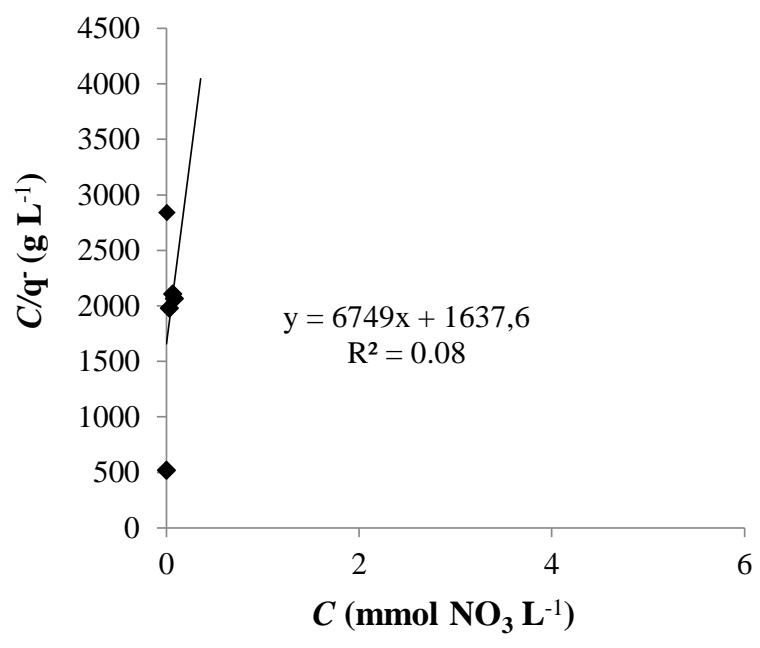

Gambar 2. Bentuk persamaan linear Langmuir Andisol Kawah Putih 0-15 cm.

Parameter persamaan Freundlich dan nilai $\mathrm{R}^{2}$ ditunjukkan pada Tabel 3. Nilai $\mathrm{R}^{2}$ persamaan Freundlich mempunyai nilai berkisar dari 0.810 sampai dengan 0.999 . Hal ini menunjukkan bahwa hubungan antara erapan nitrat dengan konsentrasi nitrat dalam larutan kesetimbangan dapat dengan baik disimulasikan dengan persamaan Freundlich. Gambar 3 adalah contoh persamaan Freundlich dalam bentuk linear Andisol Kawah Putih 0-15 cm mempunyai $\mathrm{R}^{2}$ 0.997. Nilai Konstanta K mengindikasikan nilai erapan maksimum. Nilai $\mathrm{K}$ dan $\mathrm{n}$ berbeda pada setiap order dan kedalaman tanah. Andisol Pengalengan, Andisol Lembang mempunyai nilai $\mathrm{K}$ yang fluktuatif pada tiap kedalaman, sedangkan pada Andisol Cimacan, dan Andisol Kawah Putih, nilai $\mathrm{K}$ meningkat dengan meningkatnya kedalaman. Nilai konstanta $\mathrm{n}$ pada persamaan Freundlich menunjukkan nilai positif. Nilai erapan maksimum $\mathrm{K}$ dan konstanta $\mathrm{n}$ Andisol kawah putih kedalaman 0-15 cm terbesar dibandingkan dengan tanah-tanah lainya.

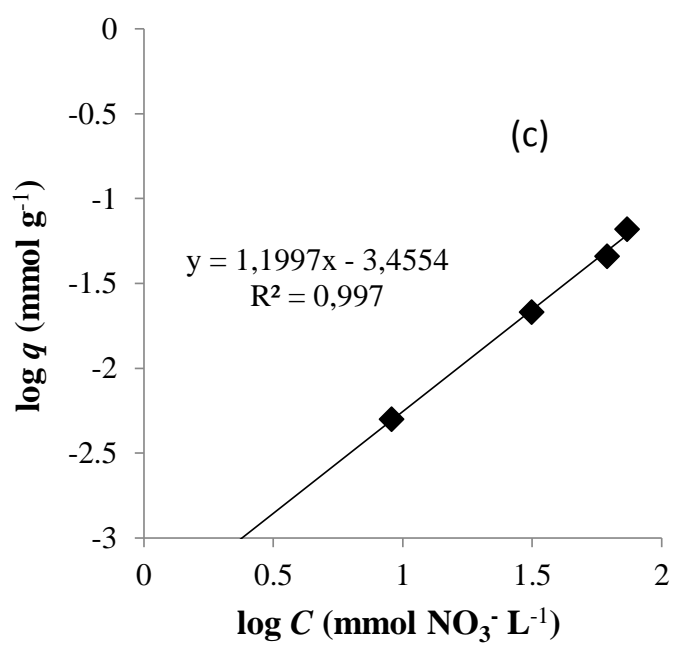

Gambar 3. Bentuk persamaan linear Freundlich Andisol Kawah Putih 0-15 cm. 
Tabel 1. Sifat fisiko-kimia Andisols

\begin{tabular}{|c|c|c|c|c|c|c|c|c|c|c|c|c|c|}
\hline Nama tempat & Order Tanah & Kedalaman $(\mathrm{cm})$ & $\mathrm{pH}\left(\mathrm{H}_{2} \mathrm{O}\right)$ & $\begin{array}{c}\mathrm{KTK} \\
\left(\mathrm{cmol}_{\mathrm{c}} \mathrm{kg}^{-1}\right)\end{array}$ & P Bray $\left(\mathrm{mg} \mathrm{P}_{2} \mathrm{O}_{5} \mathrm{~kg}^{-1}\right)$ & C-organik (\%) & N Total (\%) & $\begin{array}{c}\mathrm{Al}_{\mathrm{o}} \\
\left(\mathrm{g} \mathrm{kg}^{-1}\right) \\
\end{array}$ & $\begin{array}{c}\begin{array}{c}\mathrm{Fe}_{\mathrm{o}} \\
\left(\mathrm{g} \mathrm{kg}^{-1}\right)\end{array} \\
\end{array}$ & $\begin{array}{c}\mathrm{Al}_{0}+1 / 2 \mathrm{Fe}_{\mathrm{o}} \\
\left(\mathrm{g} \mathrm{kg}^{-1}\right)\end{array}$ & $\begin{array}{c}\mathrm{Al}_{\mathrm{d}} \\
\left(\mathrm{g} \mathrm{kg}^{-1}\right)\end{array}$ & $\begin{array}{c}\begin{array}{c}\mathrm{Fe}_{\mathrm{d}} \\
\left(\mathrm{g} \mathrm{kg}^{-1}\right)\end{array} \\
\end{array}$ & Klei $(\%)$ \\
\hline Pengalengan & Andisol & $0-21$ & 5.94 & 34.9 & 57.1 & 8.16 & 0.61 & 21.7 & 9.79 & 26.6 & 4.50 & 30.3 & 36.0 \\
\hline Pengalengan & Andisol & $21-52$ & 5.94 & 31.8 & 79.3 & 5.19 & 0.38 & 105 & 12.5 & 111 & 5.40 & 35.7 & 57.5 \\
\hline Pengalengan & Andisol & $52-83$ & 5.87 & 21.4 & 96.5 & 3.25 & 0.24 & 91.0 & 15.5 & 98.8 & 4.28 & 35.9 & 62.3 \\
\hline Lembang & Andisol & $0-16$ & 5.46 & 35.3 & 63.9 & 7.25 & 0.54 & 40.5 & 5.55 & 43.3 & 3.83 & 33.4 & 41.6 \\
\hline Lembang & Andisol & $16-36$ & 5.61 & 30.5 & 75.3 & 4.33 & 0.33 & 92.3 & 9.24 & 96.9 & 4.28 & 32.2 & 46.8 \\
\hline Lembang & Andisol & $36-70$ & 5.27 & 30.6 & 80.0 & 7.86 & 0.28 & 74.9 & 8.71 & 79.3 & 6.08 & 37.0 & 46.2 \\
\hline Lembang & Andisol & $70-100$ & 5.76 & 39.0 & 86.0 & 8.27 & 0.29 & 61.1 & 10.4 & 66.3 & 8.32 & 44.7 & 44.7 \\
\hline Cimacan & Andisol & $0-40$ & 5.06 & 21.4 & 60.5 & 2.65 & 0.21 & 14.8 & 11.5 & 20.6 & 2.33 & 43.1 & 16.7 \\
\hline Cimacan & Andisol & $40--80$ & 4.71 & 18.4 & 49.2 & 1.15 & 0.15 & 22.0 & 12.9 & 28.5 & 2.98 & 59.9 & 32.4 \\
\hline Kawah Putih & Andisol & $0-15$ & 4.89 & 28.4 & 196 & 8.88 & 0.54 & 9.89 & 7.94 & 13.9 & 6.77 & 37.2 & 16.2 \\
\hline Kawah Putih & Andisol & $15-60$ & 5.82 & 15.7 & 84.5 & 6.30 & 0.29 & 87.8 & 8.45 & 92.0 & 7.41 & 40.4 & 46.0 \\
\hline Malangbong & Andisol & $0-20$ & 6.27 & 16.7 & 124 & 1.93 & 0.19 & 7.20 & 16.1 & 15.3 & 7.67 & 66.9 & 71.6 \\
\hline Batu malang & Andisol & $0-20$ & 7.11 & 23.6 & 202 & 4.98 & 0.47 & 67.7 & 34.7 & 85.1 & 14.2 & 15.3 & 19.2 \\
\hline Cicalengka & Andisol & $0-20$ & 5.40 & 24.5 & 83.8 & 2.89 & 0.29 & 6.60 & 28.5 & 20.9 & 5.11 & 40.7 & 48.6 \\
\hline Darandang & Andisol & $0-20$ & 5.14 & 13.8 & 89.5 & 2.17 & 0.22 & 14.2 & 14.7 & 21.6 & 12.8 & 81.6 & 68.8 \\
\hline Lembang & Andisol & $0-20$ & 5.16 & 34.0 & 134 & 7.94 & 0.49 & 212 & 92.5 & 258 & 25.6 & 41.2 & 16.2 \\
\hline Ngantang & Andisol & $0-20$ & 6.56 & 16.7 & 302 & 1.55 & 0.17 & 15.2 & 20.9 & 25.7 & 3.10 & 13.6 & 11.0 \\
\hline lembang & Andisol & $0-20$ & 5.34 & 27.0 & 126 & 7.02 & 0.68 & 180 & 59.2 & 210 & 22.8 & 32.8 & 36.0 \\
\hline Minimum & & & 4.71 & 13.8 & 49.2 & 1.15 & 0.15 & 6.60 & 5.55 & 13.9 & 2.33 & 13.6 & 11.0 \\
\hline Maximum & & & 7.11 & 39.0 & 302 & 8.88 & 0.68 & 212 & 92.5 & 258 & 25.6 & 81.6 & 71.6 \\
\hline Rata-rata & & & 5.63 & 25.8 & 111 & 5.10 & 0.35 & 62.4 & 21.1 & 73.0 & 8.19 & 40.1 & 39.0 \\
\hline Stdev & & & 0.61 & 7.73 & 64.3 & 2.67 & 0.16 & 59.44 & 22.0 & 67.9 & 6.64 & 16.3 & 19.2 \\
\hline
\end{tabular}


Tabel 2. Parameter persamaan Langmuir

\begin{tabular}{ccccc}
\hline Lokasi & $\begin{array}{c}\text { Kedalaman } \\
(\mathrm{cm})\end{array}$ & $\begin{array}{c}K \\
\left(\mathrm{~L} \mathrm{mmol}^{-1}\right)\end{array}$ & $\begin{array}{c}b \\
\left(\mathrm{mmol} \mathrm{g}^{-1}\right)\end{array}$ & $\begin{array}{c}\mathrm{R}^{2} \text { persamaan } \\
\text { linear langmuir }\end{array}$ \\
\hline Pengalengan & $0-21$ & -1.97 & -3.86 & 0.02 \\
Pengalengan & $21-52$ & -1.33 & -2.81 & 0.32 \\
Pengalengan & $52-83$ & -13.7 & -1.70 & 0.15 \\
Lembang & $0-16$ & -8.30 & -3.45 & 0.27 \\
Lembang & $16-36$ & -2.78 & -6.26 & -0.06 \\
Lembang & $36-70$ & -8.15 & -1.89 & 0.99 \\
Lembang & $70-100$ & -11.4 & -1.20 & 0.51 \\
Cimacan & $0-40$ & -7.25 & -3.05 & 0.35 \\
Cimacan & $40-80$ & -5.50 & -4.46 & 0.86 \\
Kawah Putih & $0-15$ & 4.12 & 0.00 & 0.08 \\
Kawah Putih & $15-60$ & -2.10 & -0.00 & 0.11 \\
Malangbong & $0-20$ & -2.09 & -7.41 & 0.02 \\
Batu malang & $0-20$ & -2.18 & -3.12 & 0.00 \\
Cicalengka & $0-20$ & -1.33 & -6.50 & 0.96 \\
Darandang & $0-20$ & -7.00 & -3.53 & 0.83 \\
Lembang & $0-20$ & -0.14 & -0.00 & 0.93 \\
Borobudur & $0-20$ & -0.45 & -7.90 & 0.16 \\
Ngantang & $0-20$ & -1.72 & -5.30 & 0.02 \\
Lembang & $0-20$ & 0.20 & 0.00 & 0.06 \\
\hline
\end{tabular}

Tabel 3. Parameter persamaan Freundlich

\begin{tabular}{lccccc}
\hline \multicolumn{1}{c}{ Lokasi } & Order Tanah & Kedalaman $(\mathrm{cm})$ & $\mathrm{K} \mathrm{x} \mathrm{10}^{-6}$ & $\mathrm{n} \mathrm{x} \mathrm{10}{ }^{-2}$ & $\mathrm{R}^{2}$ persamaan linear freundlich \\
\hline Pengalengan & Andisol & $0-21$ & 98.4 & 102 & 0.868 \\
Pengalengan & Andisol & $21-52$ & 0.64 & 36.3 & 0.957 \\
Pengalengan & Andisol & $52-83$ & 1102 & 96.1 & 0.986 \\
Lembang & Andisol & $0-16$ & 169 & 76.8 & 0.810 \\
Lembang & Andisol & $16-36$ & 27.6 & 73.8 & 0.928 \\
Lembang & Andisol & $36-70$ & 53.8 & 71.5 & 0.983 \\
Lembang & Andisol & $70-100$ & 16.1 & 53.6 & 0.915 \\
Cimacan & Andisol & $0-40$ & 246 & 85.6 & 0.880 \\
Cimacan & Andisol & $40--80$ & 170 & 92.2 & 0.993 \\
Kawah Putih & Andisol & $0-15$ & 1191 & 131 & 0.900 \\
Kawah Putih & Andisol & $15-60$ & 350 & 83.4 & 0.997 \\
Malangbong & Andisol & $0-20$ & 1.00 & 40.2 & 0.937 \\
Batu malang & Andisol & $0-20$ & 308 & 107 & 0.938 \\
Cicalengka & Andisol & $0-20$ & 30.0 & 58.6 & 0.914 \\
Darandang & Andisol & $0-20$ & 191 & 83.8 & 0.988 \\
Lembang & Andisol & $0-20$ & 1297 & 82.4 & 0.934 \\
Ngantang & Andisol & $0-20$ & 108 & 97.8 & 0.886 \\
Lembang & Andisol & $0-20$ & 48.3 & 52.6 & 0.877 \\
\hline
\end{tabular}


Nilai konstanta $\mathrm{K}$ persamaan Freundlich sangat rendah (Tabel 3) mengindikasikan bahwa jumlah nitrat yang dierap oleh koloid tanah sangat kecil. Hal ini menunjukkan bahwa nitrat sangat mobil di dalam larutan tanah. Hamdi et al. (2013) mendapatkan nilai K persamaan Freundlich juga relatif rendah untuk tanah Tunisia.

\section{Hubungan Antara Nilai K dan n Persamaan Freundlich dengan Beberapa Sifat Fisiko-Kimia Andisol}

Hasil uji korelasi sederhana antara beberapa sifat fisiko-kimia Andisol dengan nilai $\mathrm{K}$ dan $\mathrm{n}$ persamaan Freundlich disajikan pada Tabel 4. Nilai K persamaan Freundlich berkorelasi positif dengan total $\mathrm{C}, \mathrm{Al}_{\mathrm{o}}, \mathrm{Fe}_{\mathrm{o}}, \mathrm{Al}_{\mathrm{d}}$ dan $\mathrm{Al}_{\mathrm{o}}+1 / 2 \mathrm{Fe}_{\mathrm{o}}$. Sedangkan untuk kadar klei (\%) nilai $\mathrm{K}$ Freundlich menunjukkan korelasi negatif. Korelasi paling besar adalah korelasi nilai $\mathrm{K}$ Freundlich dengan $\mathrm{Fe}_{\mathrm{o}}$ yaitu 0.39. Sementara nilai $n$ hanya berkorelasi positif dengan Corganik.

Uji korelasi menunjukkan bahwa kapasitas erapan nitrat sangat ditentukan oleh kadar dari $\mathrm{Al}$ dan $\mathrm{Fe}$ hidrus oksida yang amorf dengan kekuatan ikatan yang sangat bervariasi. Hal ini sesuai dengan yang didapat oleh Tani et al. (2004) bahwa alofan dan $\mathrm{Al}$ dan Fe hidrus oksida yang amorf menjadi komponen penting dalam mengerap nitrat.

Tabel 4. Korelasi beberapa sifat fisiko-kimia tanah dengan nilai $\mathrm{K}$ dan n persamaan Freundlich

\begin{tabular}{cccccccc}
\hline & $\mathrm{C}$-org & $\mathrm{Al}_{\mathrm{o}}$ & $\mathrm{Fe}_{\mathrm{o}}$ & $\mathrm{Al}_{\mathrm{o}}+1 / 2 \mathrm{Fe}_{\mathrm{o}}$ & $\mathrm{Al}_{\mathrm{d}}$ & $\mathrm{Fe}_{\mathrm{d}}$ & $\begin{array}{c}\text { Klei } \\
(\%)\end{array}$ \\
\cline { 2 - 8 } $\mathrm{K}$ & 0.27 & 0.32 & 0.39 & 0.35 & 0.32 & -0.07 & -0.28 \\
$\mathrm{n}$ & 0.10 & -0.25 & -0.09 & -0.23 & -0.12 & -0.28 & -0.51 \\
\hline
\end{tabular}

\section{SIMPULAN}

Sifat fisiko-kimia Andisol beragam, hal ini dapat dilihat dari nilai standart deviasi yang diperoleh. Data erapan nitrat dengan baik disimulasikan dengan persamaan Freundlich. Nilai K yang merupakan konstanta erapan maksimum persamaan Freundlich untuk semua contoh tanah digunakan sangat kecil mengindikasikan bahwa nitrat sangat mobil di dalam larutan tanah.

Nilai $\mathrm{K}$ persamaan Freundlich berkorelasi positif dengan $\mathrm{C}$-organik, $\mathrm{Al}_{\mathrm{o}}, \mathrm{Fe}_{\mathrm{o}}, \mathrm{Al}_{\mathrm{o}}+1 / 2$ dan $\mathrm{Al}_{\mathrm{d}}$. Sementara nilai konstanta $\mathrm{n}$ hanya berkorelasi positif dengan $\mathrm{C}$ organik. C-organik, $\mathrm{Al}_{\mathrm{o}}, \mathrm{Fe}_{\mathrm{o}}, \mathrm{Al}_{\mathrm{o}}+1 / 2 \mathrm{Fe}_{\mathrm{o}}$, dan $\mathrm{Al}_{\mathrm{d}}$ dapat digunakan untuk menduga erapan nitrat.

\section{UCAPAN TERIMA KASIH}

Penulis mengucapkan terima kasih kepada RISTEKDIKTI melalui dana BOPTN dan Lembaga Penelitian dan Pengabdian Kepada Masyarakat Institut Pertanian Bogor atas dana yang diberikan sehingga penelitian ini dapat dilakukan.

\section{DAFTAR PUSTAKA}

[Balittan] Balai Penelitian Tanah. 2009. Analisis Kimia Tanah, Tanaman, Air dan Pupuk. Balai Penelitian Tanah, Bogor.
Fox, R.L. and E.J. Kamprath. 1970. Phosphate sorption isotherm for evaluating the phosphate requirements of soils. Soil Sci. Soc. Am., 34: 902907.

Hamdi, W., F. Gamaoun, D.S. Pelster and M. Seffen. 2013. Nitrate sorption in agricultural soil profile. Applied and Environmental Soil Science, 2013: 1-7.

Hartono, A., S. Funakawa and T. Kosaki. 2005. Phosphorus sorption-desorption characteristics of selected acid upland soils in Indonesia, Soil Sci. Plant Nutr. 51(6): 787-799.

Hartono, A. 2007. The effect of calcium silicate on the phosphorous sorption characteristics of Andisol Lembang West Java. J. Tanah Lingk., 10: 14-19.

Hartono, A., S. Anwar dan N. Ruliana, 2019. Karakterisasi Pelepasan Nitrat pada Andisol di Jawa Barat dan Jawa Tengah. Jurnal Ilmu Tanah dan Lingkungan, 21(1): 16-20.

Hartono, A., S. Anwar dan C.M. Lutfi. 2007. Studi Erapan Fosfor, Belerang dan Boron pada Tanah Andisol Sukamantri, Latosol Darmaga dan Grumusol Cihea. Seminar Kongres Nasional IX HITI.

Hartono, A. dan R. Bilhaq. 2014. Effects of silicate application on the release pattern of native inorganic phosphorus from Andisol soil in Lembang, Indonesia using successive resin extraction. J. ISSAAS, 20(2): 43-50.

Maeda, M, Hara H, Ota T. 2008. Deep-soil adsorption of nitrate in a Japanese Andisol in response to different nitrogen sources. Soil Sci. Soc. Amer. J., 72: 702-710.

McKeague, J.A. and J.H. Day. 1966. Dithionite and oxalate extractable $\mathrm{Fe}$ and $\mathrm{Al}$ as aids in differentiating various classes of soils. Can. J. Soil Sci., 46:13-22.

Mehra, P.O. and M.L. Jackson. 1960. Iron oxide removal from soils and clays by dithionite-citrate system buffered with sodium bicarbonate. Clays Clay Miner., 7: 317-327.

Tan, K.H. 1965. The Andosols in Indonesia. Soil Sci. 99: 375-378.

Tan, K.H. and J. Van Schuylenborg. 1961. On the classification and genesis of soils developed over acid volcanic material under humid tropical conditions. Neth. J. Agr. Sci., 9: 41-54.

Tani, M., T. Okuten, M. Koike, K. Kuramochi and R. Kondo. 2004. Nitrate adsorption in some Andisols developed under different moisture conditions. Soil Sci. Plant Nutr., 50: 439-446.

Van Ranst, E., S.R. Utami, J. Vanderdeelen and J. Shamshuddin. 2004. Surface reactivity of Andisols on volcanic ash along the Sunda arc crossing Java Island, Indonesia. Geoderma. 123: 193-203.

Wada, K. 1959. Reactions of phosphate with allophane and halloysite. Soil Sci., 87: 325-330. 